\title{
GREENHOUSE GAS MITIGATION POTENTIAL OF FOREST BIOFUEL ORIGINATED IN LATVIA
}

Ieva LİCīTE,. Latvian State Forest Research Institute 'Silava', 111 Rigas str, Salaspils, LV-2169, Latvia, ieva.licite@silava.lv Kristaps MAKOVSKIS, Latvian State Forest Research Institute "Silava", 111 Rigas str, Salaspils, LV-2169, Latvia kristaps.makovskis@silava.lv

Santa KALËJA, Latvian State Forest Research Institute 'Silava', 111 Rigas str, Salaspils, LV-2169, santa.kaleja@silava.lv

Agris ZIMELIS, Latvian State Forest Research Institute 'Silava', 111 Rigas str, Salaspils, LV-2169, Latvia, agris.zimelis@silava.lv Jordane CHAMPION, Latvian State Forest Research Institute 'Silava', 111 Rigas str, Salaspils, LV-2169, Latvia jordane.champion@silava.lv

Andis LAZDIN̦Š, Latvian State Forest Research Institute 'Silava', 111 Rigas str, Salaspils, LV-2169, Latvia, andis.lazdins@silava.lv (corresponding author)

Latvia is one of the largest exporters of pellets in Europe, and at the same time share of biofuel in energy production in Latvia is also one of the largest between the developed countries. Rapid increase of biofuel production and export raises questions about sustainability of forest sector and contribution of the forest biofuel produced in Latvia to the greenhouse gas (GHG) balance in Europe. Sustainability of forest biofuel is broadly discussed issue in Baltic states; particularly, due to continuous increase of production and export of wood pellets. GHG mitigation potential of the forest biofuel is one of the sustainability aspects surrounded by multiple speculations, which has to be addressed by comprehensive comparison of GHG fluxes due to production and use of forest biofuel and substituted fossil fuel. Assessment of the GHG mitigation potential of forest biofuel is complex process requiring multiple activity data and assumptions. Particular complexity of calculation is determined by the need to use harmonized approach for the whole calculation period. The assessment of the climate change mitigation in this study is based on the methods applied in National GHG inventory and literature data on GHG emissions due to production and delivery of substituted fossil fuel and forest biomass including demolition wood. According to the study results substitution effect of the forest biofuel in Latvia continuously increases since 2000, mainly due to export of biofuel, reaching $14323 \mathrm{Gg} \mathrm{CO}_{2}$ eq. in 2020 (by 30\% more than the net GHG emissions in Latvia in 2019). Electricity production in pellet factories, in spite of major reduction of GHG emissions in the production process, has minor role in the total substitution effect.

Keywords: greenhouse gas, forest biofuel, substitution effect

\section{INTRODUCTION}

The net GHG emissions in Latvia in 2019 was $12.6 \cdot 10^{6}$ tons $\mathrm{CO}_{2}$ eq. excluding Land Use, Land Use Change and Forestry (LULUCF) sector and $12.7 \cdot 10^{6}$ tons $\mathrm{CO}_{2}$ eq. with LULUCF sector (Ministry of Environmental Protection and Regional Development, 2021a). LULUCF sector in Latvia is a net source of GHG emissions due to GHG emissions from organic soils, mostly, croplands and grasslands (about $4 \cdot 10^{6}$ tons $\mathrm{CO}_{2}$ eq.). Similarly to other EU countries Latvia recently approved the target to reach climate neutrality in 2050 by ratification of Paris agreement (UNFCCC, 2015) and even more, agriculture, forestry and other land use (AFOLU) sector has challenging target to reach climate neutrality already in 2035 (European Commission, 2021). According to this strategic target the GHG emissions in Latvia has to be reduced by more than $2.2 \cdot 10^{6}$ tons $\mathrm{CO}_{2}$ eq. $\mathrm{yr}^{-1}$ during the following 15 years in comparison to current situation and by more than $6 \cdot 10^{6}$ tons $\mathrm{CO}_{2}$ eq. $\mathrm{yr}^{-1}$ if compared to the GHG projections in 2025-2035 (Ministry of Environmental Protection and Regional Development, 2021b). The LULUCF sector will have important role in reaching this target because of considerably potential to decrease GHG emissions and to contribute to the national target by the increase of deliveries of biomass including forest bioenergy and by implementation of the climate change mitigation measures in forest land, cropland, grassland and wetlands.

In spite local consumption of forest biofuel is stagnating during the recent years, it significantly increase in the export markets, particularly due to export of pellets to other European countries substituting coal in their heat \& power plants with biomass. This resource is appearing in Latvia's GHG inventory as carbon losses in LULUCF sector (Ministry of Environmental Protection and Regional Development, 2021a). Due to this fact it is important to quantify actual contribution of forest sector to the climate change mitigation and it's potential to contribute to the national GHG balance, if forest biofuel is consumed locally and high GHG emissions due incineration of forest biofuel in households are reduced by modernization of heating systems.

Copyright () 2021 The Authors. Published by Vytautas Magnus University. This is an open-access article distributed under the terms of the Creative Commons Attribution License (CC BY 4.0), which permits unrestricted use, distribution, and reproduction in any medium, provided the original author and source are credited. 
The scope of the study is to estimate GHG emissions due to production and delivery of forest biofuel from Latvia to local and export markets and to evaluate substitution effect of forest biofuel. All kind of forest resources are considered in the study, including recycled wood and underutilized forest resources including harvesting residues, thus providing insight in the actual substitution effect and it's potential to grow.

\section{METHODS}

Forest resources in Latvia in the study are evaluated according to activity data and assumptions used in development of forest reference level; particularly, management assumptions (harvest intensity by species, forest regeneration and thinning probabilities) and forest area according to the reference period (2000-2009) and projections of forest growth and utilization rate in 2010-2020 according to assumptions on forest management intensities as set in the forest reference level calculations. Actual "business as usual" scenario is used to estimate forest growth between 2010 and 2018, as well as for the projections of forest growth in 2019-2020 (Lazdiñš et al., 2019; Šnepsts et al., 2018). Data from National GHG inventory are used in calculations of forest growth, harvests and production of HWP (Ministry of Environmental Protection and Regional Development, 2021a).

Forest biofuel resources are evaluated as potential, technically and economically accessible and actually produced resources. Evaluation of forest biofuel resources includes firewood, bark, wood processing residues, harvesting residues, stumps and biomass of small trees extracted in pre-commercial thinning. Potential resources includes all biomass, assuming that all biomass of harvested trees is extracted and utilized in energy sector. Technically accessible biofuel resources excludes production losses in production of stumps and harvesting residues (Lazdāns et al., 2008; LVMI Silava, 2008). GHG emissions due to pellet production are calculated according to literature data (Bergman, 2005; DNR, 2017; EUBIA, 2012; Loo and Koppejan, 2012). Actual biofuel production is determined using national energy and harvesting statistics providing information on firewood and harvesting residues production. Export and import is determined using industry statistics. Fuel consumption in forest operations is based on the Joint Stock company "Latvia's state forests" statistics on fuel consumption in harvesting, literature review on long term transport and IPCC guidelines (IPCC 2006) based emission factors (Eggleston et al., 2006).

Biofuel replacement effect is estimated by comparison of GHG emissions due to production and use of biofuel and GHG emissions due to production and use of fossil fuel. Fuel is divided into households and centralized applications, using different emission factors for households in Latvia. Electricity consumption and production (in case of biomass) is considered in calculation of substitution effect. Electricity $\mathrm{CO}_{2}$ equivalent assumed in calculation is 0.4 tons $\mathrm{CO}_{2} \mathrm{MWh}^{-1}$. Where biofuel production technologies can vary, more GHG intensive variant is considered, e.g. it is assumed that all chips are comminuted using diesel chippers. Detailed description of calculation methods is provided in the report by LSFRI Silava (Lazdinš et al., 2021). The methodology is based on the statistics on forest production, biofuel use, IPCC 2006 defaults for GHG emissions due to fuel consumption in off-road and road transport.

\section{RESULTS OF RESEARCH}

Potential resources of forest biofuel includes all biomass, assuming that all biomass of harvested trees is extracted and utilized in energy sector. Potentially available resources reflects species composition in the harvest stock - birch, spruce and pine are dominating. Total potentially available biofuel resources increased from $6.9 \cdot 10^{6}$ tons in 2000 to $7.9 \cdot 10^{6}$ tons in 2020 . If compared by type of potentially accessible biofuel, then stumps, roundwood processing residues and harvesting residues are dominating. The net calorific value of potentially available biomass increased from 128411 $\mathrm{TJ}$ in 2000 to $146964 \mathrm{TJ}$ in 2020 . The increase of potentially accessible biomass is associated with changes of species composition in the harvest stock leading to increase of proportion of firewood.

Technically accessible biofuel resources excludes production losses in extraction stumps and harvesting residues (Lazdāns et al., 2008; LVMI Silava, 2008). Total technically accessible forest resources increased from $84576 \mathrm{TJ}$ to 95241 TJ in 2020. Proportion of technically accessible resources, in contrast, slightly decreased - from $66 \%$ in 2000 to $65 \%$ in 2020 .

The potential biofuel resources in Latvia are close to the total energy demand in Latvia. If the demolition wood is accounted, theoretical output of biofuel from biomass originated in Latvia is significantly bigger than the total energy demand; however, technically accessible biofuel resources, including demolition wood, is about two thirds of the total energy demand in Latvia. Due to export of roundwood and biofuel more than half of this amount is produced abroad.

Actually produced biofuel from local resources increased from about 54432 TJ in 2000 to 70726 TJ in 2020. Harvesting residues, in spite of significant technically accessible potential, still have minor role in forest biofuel production. Dominant sources of biofuel are timber processing residues and firewood.

In 2000 actually produced biofuel in 2000 was $54 \%$ of the technically accessible resources and in 2020 it increased to $66 \%$ of the technically accessible resources; therefore, significant increase of forest biofuel production still can be reached without increase of the harvests. Relatively small utilization rate also confirms that local demand, which is the main output of low grade biofuel, e.g. stums and harvesting residues, can be significantly increased.

In 2000 bout $7 \cdot 10^{6} \mathrm{~m}^{3}$ of roundwood processing residues were produced. The most of it was produced abroad, from exported roundwood. In 2020 situation is opposite $-76 \%$ of the wood processing residues from locally originated roundwood is produced in Latvia. Calorific value of roundwood processing residues increased from 56517 TJ in 2000 to 
$58624 \mathrm{TJ}$ in 2020. In spite the totals did not changed significantly, the structure of production is now significantly different - the most of the residues are produced and transferred to biofuel in Latvia, avoiding GHG emissions due to long transport distances of raw materials.

The proportion of biofuel from the net energy demand in Latvia is rather stable $-44 \%$ in 2000 and $40 \%$ in 2020 . The share of biofuel is relatively high in Latvia in comparison to other EU countries; however, it is not increasing for 2 decades in spite of abundant amount of resources, which can be accessed without increase of intensity of utilization of forest resources. Biofuel historically is one of the most significant type of energy sources in Latvia. The role of biomass increased since early $90^{\text {ths }}$ and stagnated from 2000 to 2010. During the last decade the increase of biofuel consumption revived reaching $67919 \mathrm{TJ}$ in 2020 (Figure 1). Dominant type of biofuel in local consumption is firewood; however, proportion of wood chips is growing. In spite the total consumption of biofuel in Latvia did not increased significantly during 20 years, the structure of the consumption is changing - biofuel consumption in households reduces and industrial and centralized applications grows, reaching about $70 \%$ in 2020 (Figure 1).

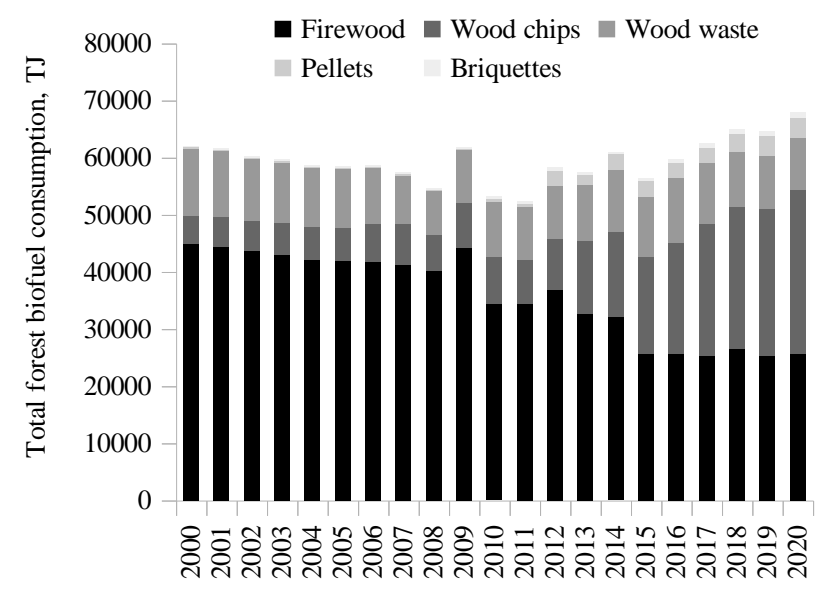

Year

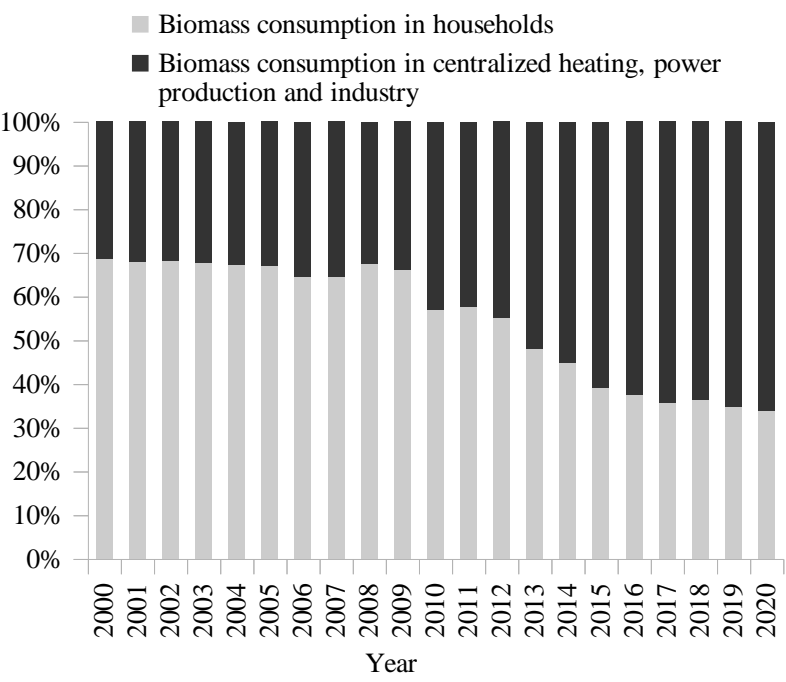

Biomass consumption in households

Biomass consumption in centralized heating, power

$100 \%$

$90 \%$

$80 \%$

$70 \%$

$60 \%$

$40 \%$

$30 \%$

$20 \%$

$10 \%$

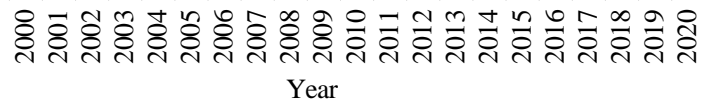

Figure 1. Forest biofuel consumption in Latvia by type of biofuel (on left side) and type of consumer (on right side).

GHG emissions due to consumption of biofuel in Latvia significantly decreased since 2000 - from $306 \mathrm{Gg} \mathrm{CO}_{2}$ eq. to $232 \mathrm{Gg} \mathrm{CO}_{2}$ eq. (by $25 \%$ ). The most of the emissions are associated with old heating systems in households. Share of GHG emissions due to incineration of imported biofuel started to growth during the last decade and reached about $18 \%$ of the total emissions due to incineration of biofuel in Latvia. Export of biofuel and utilization of demolition wood and processing residues of exported logs is another source of GHG emissions due to incineration of biomass. These emissions increased from $56 \mathrm{Gg} \mathrm{CO}_{2}$ eq. in 2000 to $168 \mathrm{Gg} \mathrm{CO}_{2}$ in 2020 , mainly due to significantly increased export of wood pellets. The total GHG emissions due to utilization of forest biofuel originated in Latvia slightly decreased since 2000 (from $362 \mathrm{Gg} \mathrm{CO}_{2}$ eq. to $357 \mathrm{Gg} \mathrm{CO}_{2}$ in 2020), in spite of significant growth of the biofuel consumption, particularly, in the export markets. The reduction of GHG emissions is mainly associated with the decrease of biofuel consumption in inefficient heating systems in households. However, there is still significant GHG mitigation potential in modernization of out-wearied and outdated heating systems. About $69 \%$ of GHG emissions due to incineration of biomass in households can be avoided by modernization of heating systems, reaching about $100 \mathrm{Gg}$ $\mathrm{CO}_{2}$ eq. in 2020 .

During the last decade pellet industry became the most significant consumer of forest biofuel and source of GHG emissions, particularly, if energy sources consumed during production and delivery of raw materials is considered. Electricity consumption is another significant source of GHG emissions considering high proportion of fossil sources in the electricity production. The net GHG emissions due to pellet production, including direct fuel consumption, production and delivery of raw materials and electricity consumption, reached $280 \mathrm{Gg} \mathrm{CO}_{2}$ eq. in 2020; however, pellet factories are also significant potential source of electricity produced from renewable sources. If pellet industry is used to full extend for electricity production, the annual production potential would reach about $803 \mathrm{GWh}_{\mathrm{el}}$. $\mathrm{yr}^{-1}$, turning pellet industry into net sink of $\mathrm{CO}_{2}$ removals ( $104 \mathrm{Gg} \mathrm{CO}_{2}$ eq.). Production and delivery of raw materials for pellet production creates about $20 \%$ of the net $\mathrm{GHG}$ emissions due to pellet production ( $38 \mathrm{Gg} \mathrm{CO}_{2}$ eq. in 2020).

Total GHG emissions due to roundwood production and delivery in Latvia, excluding firewood production and bark, increased from $119 \mathrm{Gg} \mathrm{CO}_{2}$ eq. in 2000 to $139 \mathrm{Gg} \mathrm{CO}_{2}$ eq. About $60 \%$ of the emissions are created by road transport. Additionally, $31 \mathrm{Gg} \mathrm{CO}_{2}$ eq. in 2000 and $42 \mathrm{Gg} \mathrm{CO}_{2}$ eq. is created by firewood production.

GHG emissions due to production of harvesting residues and bark increased from $6.3 \mathrm{Gg} \mathrm{CO}_{2}$ in 2000 to $11 \mathrm{Gg}$ $\mathrm{CO}_{2}$ eq. in 2020, mainly due to increase of production of harvesting residues. Total GHG emissions due to roundwood and forest biofuel production in 2000 were $157 \mathrm{Gg} \mathrm{CO}_{2}$ eq. and in $2020-192 \mathrm{Gg} \mathrm{CO}_{2}$ eq. This calculation includes harvesting, forwarding, comminution and primary road transport. GHG emissions due to biofuel production are $27 \%$ of the total logging related GHG emissions. If compared to the total GHG emissions in Latvia, excluding LULUCF sector, 
roundwood production and delivery created $1.6 \%$ of the total emissions and biofuel production $-0.4 \%$ of the total emissions in 2000 and $1.7 \%$ and $0.5 \%$, accordingly, in 2020 .

Roundwood is processed locally and externally. GHG emissions due to local processing of locally originated wood significantly increased due to development of wood processing industry in Latvia and reduction of export of logs. Considering that the most of HWP are exported, demolition wood mainly originates abroad. Here in calculation GHG emissions due to comminution and transport of demolition wood is accounted according to origin and place of processing of roundwood. In $2000 \mathrm{GHG}$ emissions due to production of biofuel from timber residues and demolition wood originated from locally grown and processed logs were $10 \mathrm{Gg} \mathrm{CO}_{2}$ eq. and $52 \mathrm{Gg} \mathrm{CO}_{2}$ eq.

GHG emissions due to production of biofuel from timber residues and demolition wood originated from locally grown and exported logs in 2000 were $21 \mathrm{Gg} \mathrm{CO}_{2}$ eq. and in 2020 they reached $26 \mathrm{Gg} \mathrm{CO}_{2}$ eq. after significant increase between 2001 and 2018. GHG emissions due to production of biofuel from pulpwood processing residues remains stable after continuous increase till 2010. GHG emissions due to processing of demolition wood continuously increases due to significant input into the HWP carbon pool during previous years. GHG emissions due to roundwood processing significantly decreases till 2020 due to reduction of export of roundwood from Latvia.

GHG emissions due to processing of imported logs and demolition wood originated from imported logs increased from $0.6 \mathrm{Gg} \mathrm{CO}_{2}$ eq. in 2000 to $5.3 \mathrm{Gg} \mathrm{CO}_{2}$ eq in 2020 with significant decrease during the period of the economic crisis in 2008-2011.

Total GHG emissions due to production of timber processing residues and demolition wood increased from $32 \mathrm{Gg}$ $\mathrm{CO}_{2}$ eq. in 2000 to $83 \mathrm{Gg} \mathrm{CO}_{2}$ eq. in 2020 .

Substitution effect of forest biofuel is calculated assuming that instead of biofuel coal is used, which corresponds to historical situation in Latvia, as well as in the export markets. GHG emissions due to use of fossil fuel instead of forest biofuel locally would reach $5947 \mathrm{Gg} \mathrm{CO}_{2}$ eq., mostly due to $\mathrm{CO}_{2}$ emissions, which are compensated by forest growth in case of utilization of forest biofuel. In 2020 these emissions would decrease to $5748 \mathrm{Gg} \mathrm{CO}_{2}$ eq. GHG emissions due to substitution of biofuel originated in Latvia with coal would reach $4308 \mathrm{Gg} \mathrm{CO}_{2}$ eq. in 2000 and $7327 \mathrm{Gg} \mathrm{CO}_{2}$ eq.

Incineration related net reduction of GHG emissions due substitution of fossil fuel with forest biomass originated in Latvia was $9893 \mathrm{Gg} \mathrm{CO}_{2}$ eq. in 2000 and in 2020 it increased to $12675 \mathrm{Gg} \mathrm{CO}_{2}$ eq. (Figure 2). The proportion of externally substituted GHG emissions continuously increase. The substitution effect due to local consumption is rather stable since 2000. Total replacement effect 2020 is nearly twice bigger than the total GHG emissions without LULUCF sector in Latvia, and substitution of fossil fuel due to roundwood and forest biofuel export in 2018 is nearly as big as the net GHG emissions in Latvia in 2018.

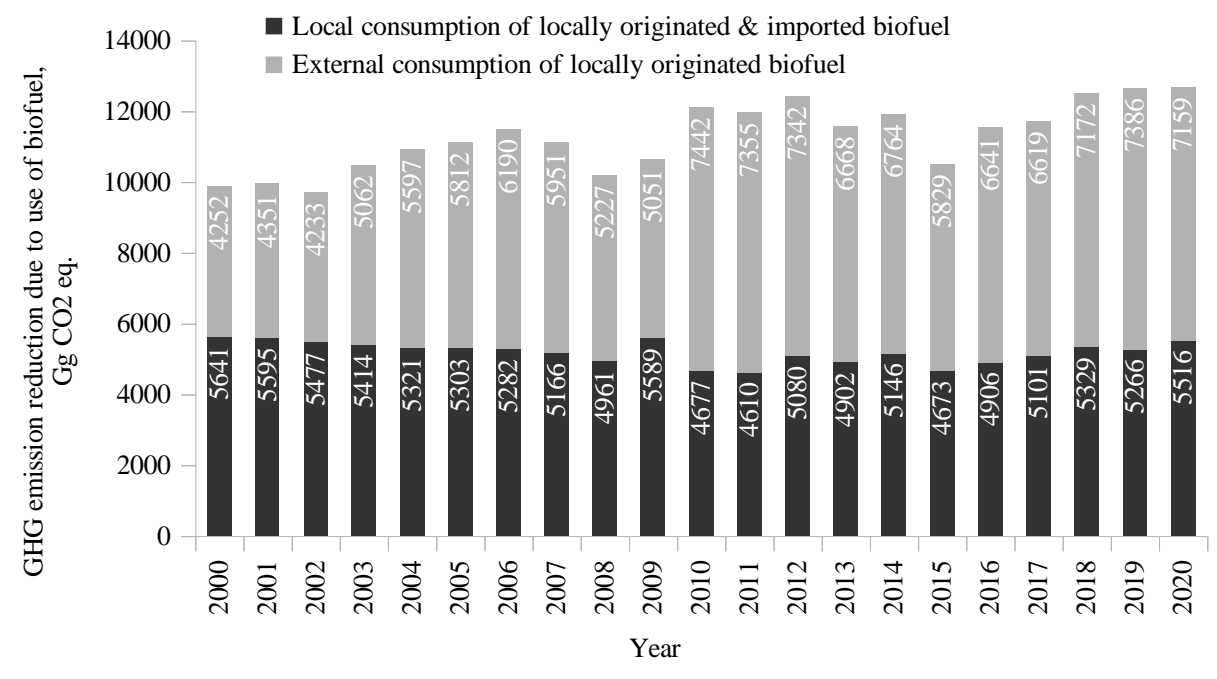

The potential GHG emissions due to production and delivery of locally substituted fossil fuel (coal and crude oil) would reach $817 \mathrm{Gg} \mathrm{CO}_{2}$ eq. in 2000 and $796 \mathrm{Gg} \mathrm{CO}_{2}$ eq. Potential GHG emissions due to production and delivery of fossil fuel substituted by forest biomass originated in Latvia are about twice higher than locally substantiated GHG emissions. They would reach $794 \mathrm{Gg} \mathrm{CO}_{2}$ eq. in 2000 and $1351 \mathrm{Gg} \mathrm{CO}_{2}$ eq. in 2020. Considerably higher GHG emissions in case if fossil fuel would not be substituted by forest biofuel are associated with origin of fossil - coal, which is imported from China, is associated with significant emissions due to output of methane into atmosphere.

The potential GHG emissions due to production, delivery and incineration of locally substituted fossil fuel would reach $6764 \mathrm{Gg} \mathrm{CO}_{2}$ eq. in 2000 and $6544 \mathrm{Gg} \mathrm{CO}_{2}$ eq. in 2020. This value corresponds to about half of the total GHG emissions in Latvia. The proportion of the substituted fossil fuel in households is continuously decreasing due to reduction of fuel consumption.

The potential GHG emissions due to production, delivery and incineration of fossil substituted by exported fuel would reach $5102 \mathrm{Gg} \mathrm{CO}_{2}$ eq. in 2000 and $8678 \mathrm{Gg} \mathrm{CO}_{2}$ eq. in 2020.

GHG emissions due to production of forest biofuel and delivery for local market, including pellet production 
facilities, increased from $120 \mathrm{Gg} \mathrm{CO}_{2}$ in 2000 to $291 \mathrm{Gg} \mathrm{CO}_{2}$ in 2020). The increase is mainly associated with electricity consumption in pellet factories. The second biggest source is production and delivery of wood processing residues, which is also the largest source of the utilized biomass resources. GHG emissions due to production of forest biofuel and delivery for external market, including deliveries of pellets, increased from $203 \mathrm{Gg} \mathrm{CO}_{2}$ in 2000 to $300 \mathrm{Gg} \mathrm{CO}_{2}$ in 2020. Similarly, as for local market, the increase of GHG emissions is mainly associated with electricity consumption in pellet factories. Total GHG emissions due to production and delivery of locally consumed and exported biofuel increased from $189 \mathrm{Gg}$ $\mathrm{CO}_{2}$ eq. in 2000 to $314 \mathrm{Gg} \mathrm{CO}_{2}$ eq. in 2020 .

The net reduction of GHG emissions due to substitution of fossil fuel with forest biofuel in 2000 was $11165 \mathrm{Gg}$ $\mathrm{CO} 2$ eq. and in 2020 it increased to $14323 \mathrm{Gg} \mathrm{CO}_{2}$ (Figure 3). The substitution effect of forest biofuel during the recent decade is significantly bigger than the net GHG emissions in Latvia in the same period. The most of the increase of the substitution effect is associated with utilization of exported biofuel and biofuel produced from exported logs.

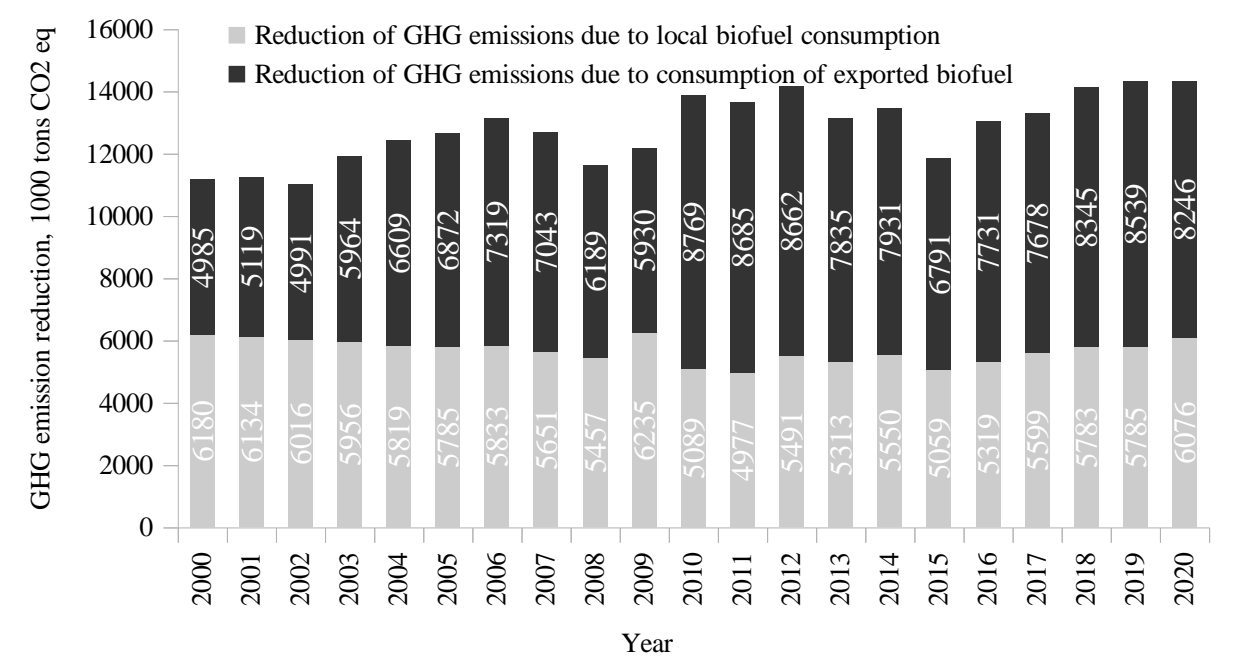

Figure 3: Reduction of GHG emissions in energy sector due to use of forest biofuel originated in Latvia.

\section{CONCLUSIONS}

1.The net calorific value of potentially accessible biofuel in Latvia, except demolition wood and biofuel produced from imported raw materials, in 2020 reached 128411 TJ. This value does not include biofuel, which could be produced in forests with management restrictions. The most significant sources of biomass, except demolition wood are wood processing residues, stumps and harvesting residues. Technically accessible resources of biomass are $65 \%$ of the theoretically available; the most significant reduction of resources due to technical issues is characteristic for stump biofuel.

2.Production of biofuel in Latvia significantly increased since 2000; particularly, harvesting residues is relatively new type of biofuel. In 2020 production of forest biofuel from local sources increased to about 70726 TJ (66\% of technically accessible resources), excluding demolition wood, imported biofuel and biofuel produced from imported roundwood. Dominant primary sources are timber processing residues and firewood. Biofuel is $44 \%$ of the net energy demand in Latvia; however, it is not increasing during the last decades in spite of increasing amount of raw materials. Structure of biofuel production significantly changed, and pellets produced mainly for external markets are becoming dominant type of biofuel.

3.GHG emissions due to local consumption of biofuel in Latvia in 2018 reached $232 \mathrm{Gg} \mathrm{CO}_{2}$ eq. (3\% of the total emissions in energy sector), excluding international transport. The most of the emissions are associated with use of biofuel in households, where significant emission reduction (by 69\%) can be reached by modernization of heating systems. Import of biofuel contributes to $18 \%$ of the net GHG emissions due to consumption of biofuel in Latvia. Total GHG emissions due to consumption of biofuel originated in Latvia in 2020 reached $362 \mathrm{Gg} \mathrm{CO}_{2}$ eq. GHG emissions due to biofuel production reached $543 \mathrm{Gg} \mathrm{CO}_{2}$ eq. in 2020; nearly half of it is associated with pellet production. Additionally, GHG emissions due to production and delivery of imported biofuel in 2020 was $101 \mathrm{Gg} \mathrm{CO}_{2}$ eq.

4.Substitution effect of the forest biofuel continuously increases since 2000, mainly due to export of biofuel, reaching $14323 \mathrm{Gg} \mathrm{CO}_{2}$ eq. in 2020. Electricity production in pellet factories, in spite of major reduction of GHG emissions due to biofuel production, has minor role in the total substitution effect.

5.Biofuel originated in Latvia have significant role in reaching climate neutrality target in Latvia and EU and maintaining resilient deliveries of sustainable forest biofuel. Use of forest biomass in energy sector still have significant potential to grow; particularly, utilization of low grade biofuel.

Acknowledgements. The study is elaborated within the scope of the post-doctoral research project "Economic and environmental assessment of biomass production in buffer zones around drainage systems and territories surrounding the protective belts of natural water streams" (agreement No. 1.1.1.2/16/I/001, application No 1.1.1.2/VIAA/3/19/437). 


\section{REFERENCES}

1. Bergman P.C.A. 2005.Combined torrefaction and pelletisation The TOP process. ECN-C-05-073; SenterNovem P.O. Box 8242 NL-3503 RE Utrecht.

2. DNR, 2017. Estimation of Greenhouse Gas Emissions. Recommended Methods for Selected Stationary Source Categories. https://www.iowadnr.gov/portals/idnr/uploads/air/insidednr/ghgemissions/ghg_estimation_methods_032217revision.pdf (2017, accessed 23 June 2018).

3. Eggleston S, Buendia L, Miwa K, Ngara T, Tanade K (eds). 2006. IPCC guidelines for national greenhouse gas inventories Volume 2 Energy. Hayama-machi (Kanagawa-ken): The Institute for Global Environmental Strategies.

4. EUBIA. European Biomass Industry Association: Economics, applications and standards. http://p9719.typo3server.info/194.0.html (2012, accessed 17 August 2012).

5. European Commission. Proposal for a Regulation of the European Parliament and of the Council amending Regulations (EU) 2018/841 as regards the scope, simplifying the compliance rules, setting out the targets of the Member States for 2030 and committing to the collective achievement of climate neutrality by 2035 in the land use, forestry and agriculture sector, and (EU) $2018 / 1999$ as regards improvement in monitoring, reporting, tracking of progress and review. https://ec.europa.eu/info/sites/default/files/revision-regulation-ghg-land-use-forestry_with-annex_en.pdf(2021, accessed 8 August 2021).

6. Lazdāns V, Lazdiņš A, Zimelis A. 2008. Celmu izstrādes tehnologijas enerǵētiskās koksnes ražošanai (Stump extraction technologies for biofuel production). Salaspils: LVMI Silava.

7. Lazdiņš A, Makovskis K, Kalēja S. 2021. Resources and use of forest biofuel in light of implementation of the national and common European climate change mitigation targets. Draft 2021-05-1. Salaspils: LSFRI Silava. https://drive.google.com/file/d/1w-NUGwhlXLJ0HQm1M2XqORUMI1gb7-D/view?usp=sharing (2021, accessed 8 August 2021).

8. Lazdiņš A, Šṇepsts G, Petaja G, Kārkliṇa I. 2019. Verification of applicability of forest growth model AGM in elaboration of forestry projections for National forest reference level. Proceedings of the 9th International Scientific Conference Rural Development, pp. 289-294. https://doi.org/10.15544/RD.2019.065

9. Loo SV, Koppejan J. 2012. The Handbook of Biomass Combustion and Co-firing. Earthscan; 2012. https://doi.org/10.4324/9781849773041

10. LVMI Silava. Energétisko šķeldu ražošana no mežizstrādes atlikumiem (Production of chips from harvesting residues). $2^{\text {nd }}$ ed. Salaspils: LVMI Silava; 2008.

11. Ministry of Environmental Protection and Regional Development. Reporting on Policies and Measures under Article 18 of Regulation (EU) No. 2018/1999 of the European Parlament and of the Council. Riga: Ministry of Environmental Protection and Regional Development of the Republic of Latvia.

12. Ministry of Environmental Protection and Regional Development. Latvia's National Inventory Report Submission under UNFCCC and the Kyoto protocol Common Reporting Formats (CRF) 1990 - 2019. Riga: Ministry of Environmental Protection and Regional Development of the Republic of Latvia.

13. Šṇepsts G, Kārkliṇa I, Lupiḳis A, Butlers A, Bārdule A, et al. 2018. Latvia's national forest accounting plan and proposed forest reference level 2021-2025. Draft 2018-03-5; Salaspils: LSFRI Silava.

14. UNFCCC. Paris Agreement. https://unfccc.int/files/meetings/paris_nov_2015/application/pdf/paris_agreement_english_.pdf (2015, accessed 17 December 2018). 